\title{
THE EFFECTIVENESS OF USING CHRONOLOGICAL PARAGRAPH STRATEGY TOWARD STUDENTS' WRITING SKILL
}

\author{
1,2Siti Wahyu Puji Anggraini \& ${ }^{1}$ Lume \\ ${ }^{1}$ English Lecturer, Universitas Nahdlatul Wathan Mataram, Indonesia \\ ${ }^{2}$ Corresponding Author Email: sitiwahyupa@gmail.com
}

\begin{tabular}{|c|c|}
\hline Article Info & Abstract \\
\hline $\begin{array}{l}\text { Article History } \\
\text { Received: December } 2020 \\
\text { Revised: December } 2020 \\
\text { Published: January } 2021\end{array}$ & $\begin{array}{l}\text { This study aims to identify the effect of chronological order strategy on } \\
\text { improving students' ability in writing paragraphs. The sample of this study was } \\
40 \text { students of SMPN } 9 \text { SATAP Pujut Central Lombok. This study employed a } \\
\text { pre-experimental method by using intact-group comparison. To gather the data, }\end{array}$ \\
\hline $\begin{array}{l}\text { Keywords } \\
\text { Chronological Strategy; } \\
\text { Writing Paragraph; }\end{array}$ & $\begin{array}{l}\text { the pre-test and post-test were distributed to the groups to collect the writing } \\
\text { score and the percentage of students' writing classification. Analysis of Variance } \\
\text { (ANOVA) was applied to testing the hypothesis. The finding data shows that there } \\
\text { was enhancement of students' classification in writing between pre-test and post- } \\
\text { test. In pre-test the average of students' classification between fair, poor and very } \\
\text { poor. But in post-test the average of students' classification improved into very } \\
\text { good, good, fair and poor. The result of data analysis indicates a significant } \\
\text { effect of using chronological order to improve students' writing ability. It } \\
\text { evidenced by the significant level was lower than } 0.05(0.00<0.05) \text {. }\end{array}$ \\
\hline
\end{tabular}

How to cite: Anggraini, S. W. P., \& Lume. (2021). The Effectiveness of Using Chronological Paragraph Strategy toward Students' Writing Skill. JOLLT Journal of Languages and Language Teaching, 9(1), 77-84. DOI: https://doi.org/10.33394/jollt.v\%vi\%i.3065

\section{INTRODUCTION}

As one of the compulsory subjects, English is considered a difficult and frightening subject for the students. Many factors influenced the students' success in learning English, either internally or externally. One of the factors that really influence the students' understanding is the wrong instructional method and instructional media (Arochman \& Yosinta, 2020). Choosing the wrong instructional method will cause the low of students' concentration and motivation in learning, that the understanding of materials that was studied is extremely low.

Writing is one of four skills (speaking, listening, reading, and writing) that must be mastered by English students. It must be mastered because it is way to communicate with another through writing. According to Roni (2018), writing can express feelings, ideas, and experience, but many students find some difficulties in learning writing. In this case, most students have a big problem in creating their idea through writing paragraph. They find failure in proving their points. They fail because they do not support their points with correct details. He also stated that in writing, some roles need more attention, such as grammatical sentence, punctuation, and mechanics. Students of junior high school often make mistake of this. It happens because there are many kinds of writing based on text target genre like writing descriptive text, narrative text, recount text and many other (Roni, 2018).

Besides that, pouring an idea into a paragraph is very challenging for junior high students to conduct. Wirantaka (2016) stated that a good paragraph will help a reader in understanding the content of the writing. A good paragraph has the coherencies that reflected the main idea in academic writing by supporting the appropriate idea. Many related study tries to find an interesting strategy in teaching writing paragraph. One strategy that found is applying the chronological order method as a prewriting technique in teaching writing 
paragraph. Bramer and Sedly (1981) state that a Chronological paragraph is used for something as simple as a recipe and for something as complex as a history book.

In academic writing, the chronological order has many uses. One of the primary ways you might use it is to write a historical review of a term paper's subject. For example, you might review the history of the labor union before you discuss the current situation. Chronological order is one of the easiest methods of organization to master writing. Chronological order, therefore, is a way of organizing the ideas in a paragraph. The objective of generalization is that learners better remember the form and function they make; the objective of the application is to use or apply a structure item learned in the previous stage to communicate information or massages.

Some studies showed that students faced difficulties in composing good complete paragraphs (Wirantaka, 2016). In higher education, students must have competences in writing. Writing can give a benefit for students in some ways. Writing in EFL motivates students to organize ideas, analyze, criticize and develop abilities in memorize (Rao, 2007). They are related with that writer's ability to retrieve and apply relevant procedures, schemas, facts, and episodes through working memory. In other words, writing strengthens students' ability to reflect, thinking and learning a language. Writing specifically helps the students produce the language by developing and connecting the ideas in the writing product. They may analyze, criticize and summarize the topic or theme being discussed. Since writing is a productive skill, it makes students to be creative and critical in composing the language (Laili \& Muflihah, 2020; Wirantaka, 2016).

In other hands, Pane (2018) finds that the problem in teaching writing is the difficulties in developing the idea. Students did not develop their paragraphs well. They usually write a simple sentence. The students profess that the problem was transforming their ideas for their mind into writing text. The second problem that I found was students' difficulty in organizing the idea. They did not know how to deliver the ideas into a good paragraph. Besides that, difficult in vocabulary, tenses and grammar also the other problem that student faced. Students encountered a problem in choosing the right word; therefore, the often asked to teacher every time they did not know the vocabulary.

Writing is not easy in practice. Writing is a process, not a 'produce' it means that every single word that students write cannot be perfect without a process (Ismiati \& Pebriantika, 2020). Every writer finishing their writing it must be review and revises, and review and revise again. Review and revises are the stage in the writing process after brainstorming and outline. This stage is to write and revise several drags until you have produced a final copy to hand in (Roni, 2018). Students need to understand a paragraph before they actually write it. Oshima and Houge (2006) stated that paragraph is a basic unit of organization in writing group-related sentences consisting of two kinds of sentences: a topic sentence and supportive statements. The number of the supporting sentences of a paragraph is not fixed, but they should be sufficient to clearly develop the main idea.

Owl (2009) clarified a paragraph as a group of closely-related sentences which deal with and develop one idea. The paragraph has been written to help the readers obtain the piece of information of the writing. Paragraph helps the readers comprehend the information within the main idea and relate it to the other paragraphs. Mayers (2006) states that there are three important parts of a paragraph. The first part is an introduction. It contains a topic sentence that outlines the aim idea of paragraph to which the rest of the paragraph should be focused. A topic sentence usually occurs in the beginning of the paragraph. In some conditions, it can occur in other positions such as in the middle or at the end of the paragraph. The second part is the body. It contains supporting sentences that develop the main idea by giving examples, details, and explanations. The third part is a conclusion. It occurs at the end of the paragraph. 
It emphasizes the point of the paragraph to be emphasized by the readers. It usually has a sense of finality.

Nunan in Khairy, (2013) mentioned that there are three elements of the paragraph to be achieved i.e. unity, coherence, and adequate development. Firstly, to have unity, a paragraph should have one main idea. Then, the main idea is developed by sufficient supporting details from at least two or more sentences. A central idea is used to control unity of the paragraph by its topic sentence. Besides that, supporting details are used to develop the topic sentence by giving more explanation to it. Second, the coherence element is the connection. Coherence can be achieved by having transitional words and phrases, pronoun reference, repeated key terms and parallelism.

Boardman and Frydenderg (2002) stated that some ways to make paragraph coherence. One of the ways is to use linking words. Coordinating conjunctions, subordinating conjunctions, prepositions, and translations are common types of linking words. The third element is adequate development. It is the last element of a paragraph to be achieved. An author can ensure the paragraph's adequate development by choosing right level of supporting details, choosing right kid $\mathrm{f}$ evidence, and having the right pattern of development. Definition of Chronological Paragraph A chronological paragraph is one that shows the sequence of events in the order they occurred.

The goal is to convey a clear sequence through time, and to do that you will have to use transitional words (first, next, then, finally, as soon as,) (Djibran, 2008). In academic writing, chronological order has many uses. One of the primary ways you might use it is to write a historical review of a term paper's subject. For example, you might review the history of labor union before you discuss the current situation. However, a chronological paragraph is not just used for historical events; it is also used in business, science and engineering to explain processes or procedures. For example, chronological order would be used to explain how to solve a math problem, how to perform a chemistry experiment, or how to set up an accounting system.

Such paragraphs are called "how to" or "process" paragraphs (Bramer and Sedly, 1981). In using chronological strategy, the author shouldn't forget about some things in writing paragraph 1) include a KWO;2) include your rough draft with "evidence of editing"; 3) double-space your paragraph; 4) underline your title; and 5) connect your topic sentence and your clincher sentence by repeating/reflecting 2-3 words (Hussen, 2015).

However, a chronological paragraph is not just used for historical events; it is also used in business, science, and engineering to explain processes or procedures. For example, chronological order would be used to explain how to solve a math problem, how to perform a chemistry experiment, or how to set up an accounting system. Such paragraphs are called "how to" or "process" paragraph. Therefore, the writer is inspired to conduct this issue to find out the effect of using chronological order to improve students' ability in writing paragraph at SMP Negeri 9 SATAP PUJUT Central Lombok. In this study, researchers try to test the hypotheses stating there is no effect of chronological order in improving students' ability in writing paragraph and stating there is a significant effect of chronological order in improving students' ability in writing paragraph. The novelty of this study lies on using chronological order in composing paragraphs.

\section{RESEARCH METHOD Research Design}

This study uses pre-experimental research by using intact-group comparison. This method uses two groups of subjects who are given different treatments. The two groups were determined without being random (for example, a class that had been formed was taken) but 
were assumed to have equal abilities in all relevant aspects, the only difference was in the treatment.

In this method, there are two groups were applied namely: the experimental group (who were given treatment) and half for the control group (who were not treated). The paradigm of the study can be described as research flowchart below:

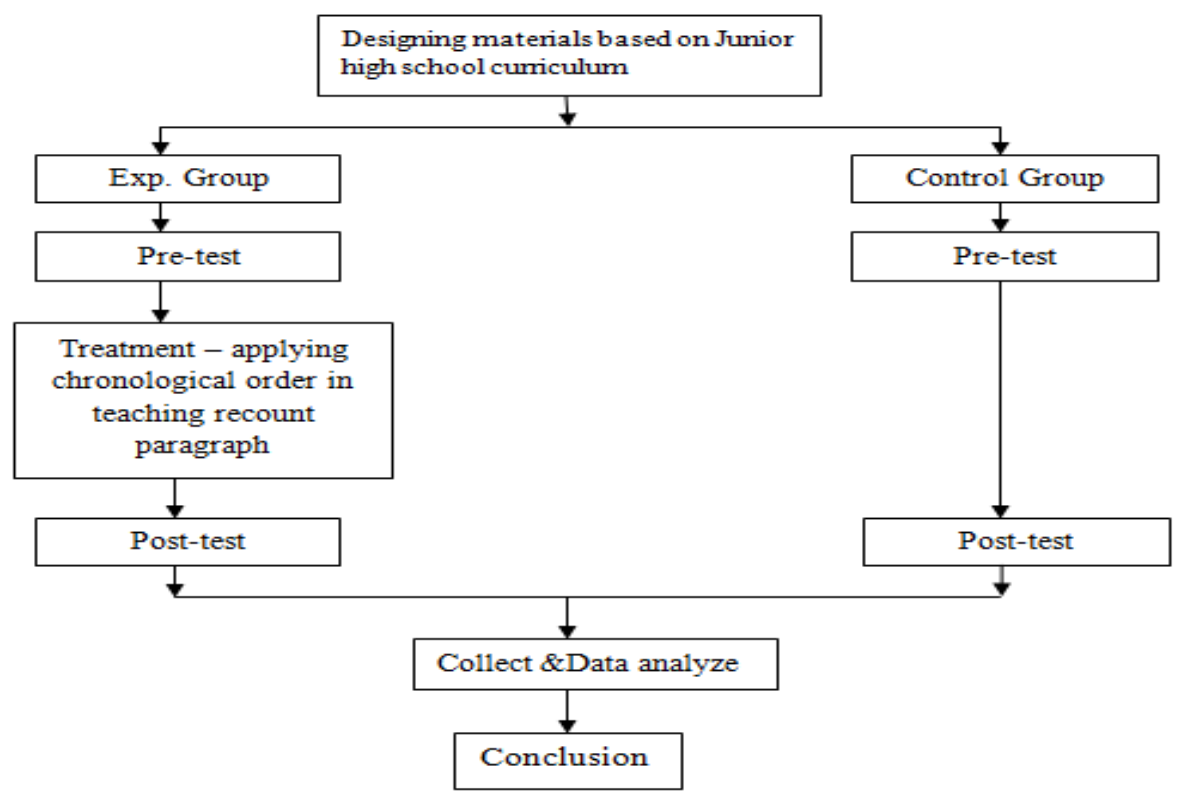

Figure 1. Research Flowchart

\section{Population and Sample}

This population of this study is all students of the third grade of SMPN 9 SATAP Pujut, which consists of 40 students. All populations are selected as the sample of this study by using probably sampling and simple random sampling as the technique. 20 students were randomly taken as the experimental group and 20 students were taken as control group. The students in the experimental group are subjected to the conventional strategy, while students in the experimental group are treated using the chronological order strategy in enhancing students' writing skills.

\section{Instruments}

The instrument of data collection uses writing tests. The writing test was distributed in the pre-test session and the post-test time. The writing aspects are assessed in the writing content, organization, vocabulary, language use, and mechanics. The pre-test was done before doing a treatment. Researchers administered a pre-test by writing a paragraph and essay. Meanwhile, the post-test was distributed in the last meeting after treatments. It is intended to find students' writing skills after giving treatment.

\section{Data Analysis}

The data of this study comprise the students' writing achievement. Students are asked to compose a complete recount text. Based on the writing score, researchers classify in some criteria, which are very good, good, fair, and poor, and very poor. Afterwards, the data gained are analyzed using statistical analysis, which is descriptive and inferential analysis. The descriptive analysis is focused on students' mean, median, mode, and standard deviation. In this study, the mean score is considered as an important one. Table 1 shows the writing classification for assessing students' writing skills. 
Table 1.

Writing Classification

\begin{tabular}{|l|l|c|}
\hline No & Classification & Score \\
\hline 1 & Very Good & $86-100$ \\
\hline 2 & Good & $71-85$ \\
\hline 3 & Fair & $56-70$ \\
\hline 4 & Poor & $41-55$ \\
\hline 5 & Very Poor & $\leq 40$ \\
\hline
\end{tabular}

Afterwards, the data are analyzed by using IBM SPSS 21 to find out the interaction between instructional strategies on writing skills. The analysis of variance (ANOVA) was applied. The instructional strategies consist of the chronological order strategy and conventional strategy in improving students' writing skills at junior high schools at Pujut.

\section{RESEARCH FINDINGS AND DISCUSSION Research Findings}

This study aimed to find out the effect of the chronological order strategy on students' writing skills at Junior High Schools at Pujut. The data show the pre-test result in the control and experimental class are different. For fair classification, the experimental group got 35\%. There are seven students who fair in writing, while the control group got $10 \%$ in which there are only two students are fair in writing. For poor classification, the experimental group got $35 \%$ in which seven students are poor in writing and the control group got $10 \%$ in which 2 students are poor in writing). Besides, experimental group got $30 \%$ in which six students are very poor in writing and the control group got $80 \%$ in which 16 students are very poor in writing. Table 3 presents the students' score and classification in writing recount texts.

Table 2

The Score of Students' Pre-Test

\begin{tabular}{llrr}
\hline No & Classification & Experimental Group & Control Group \\
\hline 2 & Fair & $35 \%$ & $10 \%$ \\
\hline 3 & Poor & $35 \%$ & $10 \%$ \\
\hline 4 & Very Poor & $30 \%$ & $80 \%$ \\
\hline
\end{tabular}

In the post-test, the data shows there are three students (15\%) from the experimental group that got very good and no students from control group who got very good score. There are 13 students $(65 \%)$ of the experimental group got good scores, and 10 students $(50 \%)$ of the control group got good scores. There are 4 students (20\%) from the experimental group got a fair score, and 7 students (35\%) of the control group got a fair score. The experimental group student got poor score while there are 3 students (15\%) of control group got poor score. The data of students' writing achievement after giving treatments can be presented in Table 4.

Table 4

The Score of Students' Post-Test

\begin{tabular}{llrr}
\hline No & Classification & experimental & \multicolumn{1}{c}{ control } \\
\hline 1 & very good & $15 \%$ & $0 \%$ \\
\hline 2 & good & $65 \%$ & $50 \%$ \\
\hline 3 & Fair & $20 \%$ & $35 \%$ \\
\hline 4 & Poor & $0 \%$ & $15 \%$ \\
\hline
\end{tabular}

Based on the data analysis of students' score, the lowest score in the experimental class was 30, and the highest score was 70 with standard deviation of 12.594 and the variance 
158.618. Meanwhile, for the control group, the pre-test score obtained the lowest score was 20 and the highest score was 60 with the standard deviation 10.437 and the variance 108.947. it means that students who are taught using the chronological order strategy was better than those who are treated using the conventional one. Besides, the data shows the post test score obtained for experimental group minimum score was 65 and the maximum score 95 with standard deviation 7.947 and the variance 63.158. Meanwhile, the students' post-test score for control group obtained the minimum score was 50 and the maximum score was 85 with standard deviation 10.259 and the variance 105.263. It indicates that the chronological order strategy was better than the conventional strategy in composing complete recount texts in writing classes.

In this study, all samples come from a normally distributed population. It is proven that the $\mathrm{p}$ value was 0.195 and the control group was 0.087 . The $\mathrm{p}$-value was higher than 0.05 . Also, the homogeneity of variance of Pre-test and post-test was stated as homogenous data. It was proven that the Leven test is 0.958 with significance or probability 0.334 . It means that the P value was higher than $(\alpha)$ value $(>0.05)$. So, it can be stated that the variance of Pre-test score is homogeny. Table 10 also obtained the Leven Statistic is 1.670 with a probability 0.204 which it is higher than 0.05 . So, it can be concluded that the variance of Post-test is also homogeneous. Thus, this study is continued to find out the interaction between groups. It was applied using ANOVA analysis. It can be presented in Table 5.

Table 5

Hypothesis Testing by ANOVA

\begin{tabular}{lrrrrr}
\hline SCORE & \multicolumn{7}{l}{} \\
\hline & Sum of Squares & df & Mean Square & F & \multicolumn{1}{c}{ Sig. } \\
\hline Between Groups & 21383.438 & 3 & 7127.813 & 65.395 & .000 \\
\hline Within Groups & 8283.750 & 76 & 108.997 & & \\
\hline Total & 29667.188 & 79 & & & \\
\hline
\end{tabular}

Table 5 shows the hypothesis testing to determine the significance effect of chronological order toward students' ability in writing paragraph. Based on the data above, it can be concluded that $\mathrm{H}_{0}$ is rejected and $\mathrm{H}_{\mathrm{a}}$ is accepted. It evidenced by the significance value was lower than $0.05(0.000<0.05)$. And we can state that there is significant effect of chronological order in improving students' ability in writing paragraph.

\section{Discussion}

Based on finding data that presented on data analysis technique, the classification of students' ability in pre-test obtained the average classification within fair, poor and very poor. After delivering the treatment, introducing chronological order in the experimental group enhances students' post-test score. The chronological order steps consist of drafting process, double-space of each paragraph, underlining the title, and connecting the topic sentence and your clincher a sentence by repeating/reflecting two or three words in the paragraph. In drafting processes, students are asked to write rough draft as some topic sentences before they compose those in a complete paragraph. In doing so, students are given some materials of writing as clues to write. This learning activity help students determine the next sentences or supporting sentences. It is in line with Cooney et al. (2018) who state students can improve writing skills through giving writing activities as much as possible. In this study, this learning is effective and it can be proven the mean score was 75. It is stated in good classification.

The second step of the chronological order is doing double-space of each paragraph produced by students. In this step, students are asked to write complete paragraphs and make double-space on those. It is intended to help students to see sentence structures and grammatical errors. Also, students can revise any part of each paragraph to be added 
information in line with the topic sentence. It is in accordance with Khezrlou (2020) who state that students need good planning and writing knowledge to compose a complete writing text such as recount texts. In this study, students feel easy to compose their writing after they have great planning to write. It is proven with students' post-test score obtained a classification grade of students' writing ability within good, fair, and poor. It is proven by the percentage within the grade. For good classification, there are ten students $(50 \%)$ who were good in writing; there are 7 students (20\%) who were fair in writing, and there are 3 students (15\%) who were still poor in writing. This finding was supported by Rony (2018) who informs that students can improve students; writing skills with providing writing clues.

On the whole, both of groups increased their ability in writing the paragraph. Even though only the experimental group gave treatment, both groups got knowledge in writing paragraphs during pre and post-tests. This statement was supported by the findings of hypothesis testing by using analysis of variance (ANOVA). The result of hypothesis testing shows that the significant value was lower than $0.05(0.00<0.05)$. It means that there is a significant effect of using chronological order to improve students' writing ability. And also, through the test $\mathrm{H} 0$ can take the hypothesis statement is rejected and $\mathrm{H}_{\mathrm{a}}$ is accepted.

\section{CONCLUSION}

Based on the percentage of students' writing classification, there is an increased classification of students' writing ability during pre-post and post-tests. Pre-test students' average classification was between fair, poor and very poor for experimental and control groups. For the post-test result, there is enhancement of students' classification in writing. For the experimental group, the students' average classification was between very good, good and fair. Meanwhile for the control group the students' average classification was between good, fair and poor. The result of hypothesis analysis also reinforces this finding by using analysis of variance that shows the significant value was lower than $0.05(0.00<0.05)$ thus making $\mathrm{H}_{0}$ is rejected and $\mathrm{H}_{\mathrm{a}}$ is accepted. And it concluded that there is a significant effect of chronological order in improving students' writing ability.

\section{ACKNOWLEDGEMENT}

Firstly, I am indebted to my Co-author Lume for continues support in finishing this research. Secondly, thanks to the headmaster of SMPN 9 SATAP Pujut for facilitated the process of collecting data. The last gratefulness to LLDIKTI under the auspices of Ministry of Research, Technology and Higher Education (Kemenristekdikti) who give opportunity to conduct PDP research and financial support to this research.

\section{REFERENCES}

Abdul, R. P., Habiri, A., Rahmiyati, A., Fitria, W., (2016). Pre-Experimental Design. Published paper. Program Studi Pendidikan Matematika: Universitas Muhamadiyah Makasar.

https://www.academia.edu/35719426/PENELITIAN_PRE_EKSPERIMEN_DAN_TR UE_EKSPERIMEN.

Arochman, T., \& Yosintha, R. (2020). Effect of using web-blog on writing instruction for English language learners. Journal of Languages and Language Teaching, 8(4), 336347. doi: https://doi.org/10.33394/jollt.v8i4.2797

Bramer., George R., \& Sedly, D. (1981). Writing for Readers. Charlese: Merill Publishing co. A bell \& Howell Company Columbus.

Crème, P., \& Lea, M. R. (2003). Writing at University, Second Edition. Maidenhead: Open University Press. 
Creswell, J.W. (2012). Educational Research: Planning, Conducting, and Evaluating Quantitative and Qualitative research. Boston: Pearson.

Cooney, A., Darcy, E., \& Casey, D. (2018). Integrating reading and writing: Supporting students' writing from source. Journal of University Teaching and Learning Practice, $15(5)$.

Djibran, F. (2008). Writing is Amazing. Jakarta: Jux Tapose.

Djiwandono, M. Soenardi. (2008). Tes Bahasa (Pegangan bagi Pengajar Bahasa). Jakarta: PT Indeks.

Hidayat, A. (2012). Uji Anova-Uji One Way ANOVA dalam SPSS. Retrieved October 10, 2020, from https://www.statistikian.com/2012/11/one-way-anova-dalam-spss.html.

Ismiati, I., \& Pebriantika, E. (2020). Designing strategies for university students' writing skill. Journal of Languages and Language Teaching, 8(1), 8-19. doi: https://doi.org/10.33394/jollt.v8i1.2210

Imran, H. A. (2017). Peran Sampling dan Distribusi Data Dalam Penelitian Komunikasi Pendekatan Kuantitatif. Journal Komunikasi dan Media, 21(1), 111-126.

Khezrlou, S. (2020). Training planning in second language narrative writing. ELT Journal, 74(1), 49-62. https://doi.org/10.1093/elt/ccz050

Laili, E., \& Muflihah, T. (2020). The effectiveness of google classroom in teaching writing of recount text for Senior High Schools. Journal of Languages and Language Teaching, 8(4), 348-359. doi: https://doi.org/10.33394/jollt.v8i4.2929

Pane, Natasha LAS. (2018). Developing the Writing Paragraph through Quick writing for Junior High School at SMP Swasta Pahlawan Nasional. Thesis: English and Literature Departement, Faculty of Language and Arts. State University of Medan

Raharjo, S. (2017). Cara melakukan uji ANOVA satu factor dengan SPSS. Retrieved October 10, 2020, from https://www.spssindonesia.com/2017/10/analisis-anova-satu-faktorspss.html.

Roni. (2018). Using Chronological Order Method to Improve Writing Ability of the Third Year Students of SMA Negeri I Pangsid Kabupaten Sidenreng Rappang. Journal of English Education and Development, Vol (1), 61 - 75.

Siahaan, S. (2008). Issues in Linguistics, First Edition. Yogyakarta: Graha Ilmu.

Sugiono. (2009). Metode Penelitian Kuantitatif, Kualitatif dan R\&D. Bandung: CV Alfabeta.

Zahrah, F. (2011). The Analysis of Major Problems Encountered by English Teachers in Teaching Sentence Structure to Deaf Students at SMPLB-B Dharma Wanita Academic Year 2011/2012. Thesis S1: Mataram University. 